\title{
E-lifestyle, Customer Satisfaction, and Loyalty among the Generation Y Mobile Users
}

\author{
Siti Hasnah Hassan ${ }^{1}$, T. Ramayah ${ }^{1}$, Osman Mohamed ${ }^{2}$ \& Amin Maghsoudi ${ }^{1}$ \\ ${ }^{1}$ School of Management, Universiti Sains Malaysia, Pulau Pinang, Malaysia \\ ${ }^{2}$ Faculty of Management, Multimedia University, Cyberjaya, Malaysia \\ Correspondence: T. Ramayah, School of Management, Universiti Sains Malaysia, 11800 Pulau Pinang, Malaysia. \\ Tel: 60-4-653-3889. E-mail: ramayah@usm.my
}

\author{
Received: September 29, 2014 Accepted: November 25, $2014 \quad$ Online Published: January 14, 2015 \\ doi:10.5539/ass.v11n4p157 \\ URL: http://dx.doi.org/10.5539/ass.v11n4p157
}

\begin{abstract}
Technology advancement is gaining a great deal of attention among young individuals. Technology has significantly impacted and changed the context and the way young people live in recent years, particularly in developing countries across Southeast Asia. Indeed, telecommunication companies have noticed the importance of e-lifestyle factors which largely contribute to their identity. This research is aimed to examine the impact of e-lifestyle on customer satisfaction and loyalty from mobile consumers in the emerging countries. The data were collected using a survey among 197 respondents from Generation Y that aged between 18 and 37 years old. The data were analyzed using SmartPLS and the results show that the second-order construct of e-lifestyle has significant effect on customer satisfaction and loyalty. The future implications and conclusion are discussed.
\end{abstract}

Keyword: e-lifestyle, customer satisfaction, loyalty, mobile user, generation $\mathrm{Y}$

\section{Introduction}

Mobile services and applications emerged due to convergence of Internet, media, IT, and advanced telecommunication technologies that has stimulated phenomenal influence by information and communication technology (ICT). Indeed, numerous different mobile services and applications are available to consumers in the telecommunication market environment. In fact, individual acceptance and adoption of mobile services have not been completely developed (Karnowski \& Jandura, 2014). This can be explained due to tremendous growth in the mobile telecommunications and dynamic nature of the market. The significant growth has remarkably impacted and changed the context and the way people live in recent years (Yu, 2011). Thereby, a myriad of service providers believe that the mobile service industry has yet to be explored and ample opportunities exist to enhance the services for the consumers.

Malaysia, in particular, has also witnessed advancement and is keeping applicable pace with global technology advancements among the emerging economies. The growth rate in the use of telecommunication facilities has increased significantly in Malaysia, especially in the rank of increasing number of mobile service subscribers. There are many explanations why consumers choose a particular type of mobile service provider. Nonetheless, one of the major factors that affect the selection of service provider is the consumer lifestyle. In fact, understanding consumer lifestyle has long been considered beneficial in tailoring and delivering appropriate services to the specific target segments. Indeed, many advertisers prefer to shape their brand relying on their potential consumer lifestyle, as different brands for a particular service segment are commonly hard to distinguish in terms of service attributes (Biel, 1992). Consequently, it is obvious that marketing communication is more effective when consumer lifestyles are fully understood. In other words, lifestyle research is of capital interest for managers to visualize their audiences more appropriately (Vyncke, 2002). In a similar vein, understanding consumer lifestyles has been considered useful in delivering suitable services to particular target segments of ICT, hence the concept of e-lifestyle has been introduced that could help marketers to decide precisely within this market (Chen \& He, 2006).

The aim of this research is to understand the consumer e-lifestyle and operationalize its concept as a second-order construct. The second objective is to determine the impact of e-lifestyle on customer satisfaction that affects loyalty. The understanding of these relationships is vital in tailoring and delivering appropriate 
services to Generation Y and services related to mobile technologies.

\section{Literature Review}

One of the major objectives of marketing activities is the enhancement and maintaining customer loyalty (Dick \& Basu, 1994). Obviously, customer loyalty has significant positive effect on the profitability of the businesses. Loyal customers, who continuously use the same service provider and ignore other rivals, will offer a long-term revenue for a company (Lam, Shankar, Erramilli, \& Murthy, 2004). In the context of mobile service industry, loyal customers are more likely to focus on long-term benefits and engage in cooperative actions beneficial for both parties. However, many mobile service providers have faced challenges due to the dynamic nature of technological advancements and rapid evolution of the Internet and electronic commerce (Wong, Chan, Ngai, \& Oswald, 2009). Thereby, building customer loyalty in the mobile service industry is not about maintaining customers overtime, but also nurturing the relationships with customers for their continuous future purchases (Rauyruen \& Miller, 2007). As previously mentioned, one of the major factors affecting customer satisfaction and loyalty is consumer e-lifestyle. The following subsection reveals details about this particular concept.

\subsection{E-lifestyle}

Traditional segmentation strategies are based on individual socio-demographic, attitudinal, or psychographic characteristics (Penz, 2006). The term psychographic puts together 'psychology' and 'demographics' to add richness of both social and behavioral sciences to demographics in order to improve understanding of consumer behaviour (Demby, 1974). The first spectrum of psychographic studies was originally rooted in personality profiles with the most frequently used scale for measuring general aspects of personality traits. However, these researches were plagued with inconsistent correlations with consumer behavior (Vyncke, 2002). In the second spectrum of psychographic research, the concept of personality has been replaced by the concept of 'lifestyle' which was introduced by Lazer (1963). To date, the term lifestyle has become prevalent amongst scholars in the field of consumer behavior, hence the term is used in this research.

Lifestyle is commonly referred to as patterns in which people live and spend their time and money (Kaynak \& Kara, 2001). Lifestyle can also be defined as patterns of action which differentiate people in order to help to understand what people do and why they do it (Chaney, 1996). Accordingly, the term lifestyle has become central, while the personality concept has become marginal to psychographic studies and the latter is currently replaced by the lifestyle concept (Vyncke, 2002). The term lifestyle is more comprehensive than that of socioeconomic and demographic characteristics (Blackwell, Miniard, \& Engel, 2001). More importantly, individual lifestyles seem to be stronger predictors of consumer behavior including use and disposition of products and services (Murry, Lastovicka, \& Austin, 1997). Thereby, decision-makers will be able to communicate with their consumers more effectively by recognizing the lifestyle factors of potential consumers (Lee, Lim, Jolly, \& Lee, 2009).

Hyper convergence of the Internet and mobile usage, particularly among the youth, has dramatically impacted and changed the way people live since the last decade (Yu, 2011). Therefore, understanding consumer lifestyles has been considered useful in delivering suitable services to particular target segments of ICT (Chen \& He, 2006). Furthermore, Yu (2011) developed and validated an e-lifestyle construct that could provide marketers some insight into what triggers people's e-lifestyles. E-lifestyle, in this research, is conceived as patterns in which people live and spend their time and money through the Internet and electronics, which this definition is consistent with that of Kaynak and Kara (2001). Lifestyle theories agreed that consumer behaviors can be predicted by a function of sociological and psychological variables. Consistently, consumer e-lifestyle is also predictable and assessable by psychological and sociological constructs (Yu, 2011).

Myriad of researches have assessed the lifestyle construct, but among various lifestyle scales, two conceptualizations are popular and broadly used. The first one is lifestyle's construct conceptualized by three dimensions of activities, interests, and opinions (AIO), originally developed by Wells and Tigert (1971). The second construct includes value, attitude, and lifestyles (VALS) rating scale, which was developed by Mitchell (1983). Wells and Tigert (1971) defined activities as actual observable behaviors, interests as the continuous paying of attention to certain objects, and opinions as responses to specific events. Since then, lifestyle has been conceptualized based on AIO approach extensively to help marketers tailor a particular service or product to various target segments (Bates, Cooper, \& Wachs, 2001; Green, Cordell, \& DiStefano, 2006; Hur, Kim, \& Park, 2010).

Mitchell (1983) developed VALS instrument by observing the relations among individual values, lives, beliefs, and actions. He explained that a mixture of personal life and perceived value determines consumer behavior, while a perceived value is a synthesis of individual beliefs, attitudes, hopes, and demands. Therefore, many 
scholars argued that value is one of the necessary constructs besides activities, interests, and opinions to assess consumer lifestyle (Lin, 2003). Interestingly, in parallel with that, Yu (2011) operationalized e-lifestyle by employing four constructs of e-activities, e-opinions, e-interests, and e-values. Furthermore, based on the theory of lifestyle, lifestyle is a set of behaviors reflecting individual psychological concerns (internal beliefs) and sociological consequences (external stimuli). This research adopts from the seminal work of Yu (2011) to conceptualize e-lifestyle construct.

\subsection{Customer Satisfaction and Loyalty}

The association between customer satisfaction and loyalty seems to be nearly intuitive. Satisfaction is employed as a prevalent marketing benchmark to measure a product's performance in the market. Previous studies have recognized customer satisfaction as a key factor in achieving customer's retention and loyalty (Levesque \& McDougall, 1996). Indeed, customer satisfaction is an overall customer attitude toward a service provider (Levesque \& McDougall, 1996, p. 14) and an emotional reaction to the differences between customer expectation and what they receive (Zineldin, 2000). There are two different operationalization for the construct of customer satisfaction; first-time post-purchase evaluation (Mano \& Oliver, 1993) and the cumulative satisfaction to overall evaluation after usage for a period of time (Fornell, 1992). For the purpose of this research, the cumulative construct of customer satisfaction is more relevant to the telecommunications sector, where customer satisfaction can be measured as the overall evaluation of the service provided by a particular mobile service provider in Malaysia. Additionally, the relationship between customer satisfaction and loyalty is assumed to be positive (Zeithaml, Berry, \& Parasuraman, 1996). This is widely recognized in previous empirical studies. Based on the above literature review, the research framework and hypothesis are proposed as below:

$\mathrm{H}_{1}$ : Consumer e-lifestyle has positive impact on customer satisfaction.

$\mathrm{H}_{2}$ : Customer satisfaction has positive significant impact on loyalty.

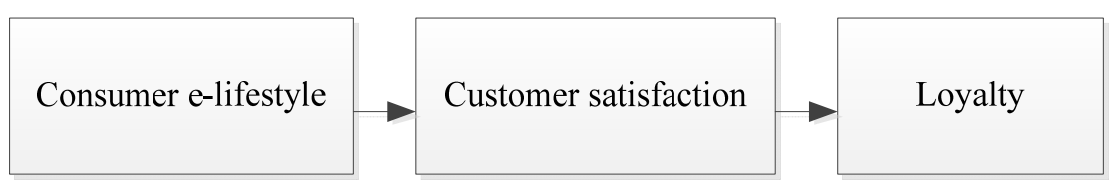

Figure 1. Proposed research framework

\section{Research Methodology}

A self-administrated questionnaire was distributed and collected from subscribers of mobile service providers in Malaysia. The unit of analysis in this study is subscribers of mobile service providers (i.e., Celcom, Digi, Maxis, and Umobile) within some areas in Malaysia that have become the subregions of continuous development, progress, wealth, peace, and quality of life according to the five-year IMT-GT Roadmap (ADB, 2008). The covered areas in Malaysia include states of Kedah, Perlis, Perak, Penang, Selangor, Kelantan, Melaka, and Negeri Sembilan. Based on the rule of thumb, the minimum number of respondents is five-to-one ratio of the number of latent variables to be tested. Since we were not able to obtain the list of total population in the suggested area, thereby a non-probability purposive sampling approach is employed whereby only mobile subscribers of the five particular mobile providers in Malaysia were chosen and the rest were excluded from the data set. The questionnaire consists of three major sections. The first section included four sub constructs underlying consumer e-lifestyle as the second-order construct. The four subcontracts include e-activities, e-opinions, e-interests, and e-values adapted from previous research (Lee et al., 2009; Mitchell, 1983; Wells \& Tigert, 1971; Yu, 2011). The second part includes customer satisfaction and loyalty. The last section gathers demographic information on the respondents such as gender, age, race, and education level. Table 1 indicates the items for the major construct of e-lifestyle including four formative indicators.

\section{Results and Discussion}

Purposive sampling method was used as the list of populations was not available. About 600 self-administered questionnaires were used for gathering data from the respondents in Malaysia. A total of 197 valid questionnaires were received by the end of data collection's period (32.8\% response rate). SmartPLS 2.0 software (Ringle, Wende, \& Will, 2005) was used to evaluate the relationships among the constructs of the research model by conducting partial least squares (PLS) analysis. PLS analysis was preferred as the methodological choice due to several reasons. First, as a covariance-based approach, it places minimal requirements on residual distributions 
and sample size to achieve a satisfactory numerical power (Hair, Sarstedt, Ringle, \& Mena, 2012). Second, it advances the choice to analyze constructs' association compared to other techniques (Acedo \& Jones, 2007). Third, it allows us to simultaneously evaluate both the measurement and structural model (Chin, 1998), while it eliminates concerns about the multicollinearity issues (Inkpen \& Birkenshaw, 1994). Fourth, it allows to analyze data during the early stage of theory development (Tsang, 2002).

Table 1. E-lifestyle and its item description

\begin{tabular}{|c|c|c|}
\hline Dimension & Item & Description \\
\hline \multirow{9}{*}{ E-activities } & & I frequently use the Internet on my mobile to .... \\
\hline & EA1 & play games or listen to online music \\
\hline & EA2 & shop for products/services. \\
\hline & EA3 & Share my opinions within network communities (e.g., Facebook, Twitter, etc.) \\
\hline & EA4 & Chat with my friends or colleagues/classmates. \\
\hline & EA5 & Arrange trips by booking flight/bus tickets, accommodation, etc. \\
\hline & EA6 & Participate in social events. \\
\hline & EA7 & Read news or get data. \\
\hline & EA8 & Download or watch movie online. \\
\hline \multirow{8}{*}{ E-interests } & & I use the Internet services on my mobile because ... \\
\hline & EI1 & I am very interested in discovering new things online. \\
\hline & EI2 & I would like to stay updated with the latest electronic development. \\
\hline & EI3 & I feel happy to use the newest technology. \\
\hline & EI4 & I like gaining knowledge through online. \\
\hline & EI5 & I like to participate in the network of social communities. \\
\hline & EI6 & I like browsing and searching on the Web. \\
\hline & EI7 & I enjoy online shopping. \\
\hline \multirow{7}{*}{ E-opinions } & & Continued development of Internet services on mobile is ... \\
\hline & EO1 & positive for our society. \\
\hline & $\mathrm{EO} 2$ & positive for our culture. \\
\hline & EO3 & positive for our education system. \\
\hline & EO4 & positive for our economy. \\
\hline & EO5 & bringing more happiness to our daily life. \\
\hline & EO6 & very important to know about the vulnerable people and situations. \\
\hline \multirow{8}{*}{ E-values } & & I believe that using the Internet on the phone ... \\
\hline & EV1 & enhances the convenience in my life. \\
\hline & EV2 & improves my job efficiency. \\
\hline & EV3 & expands my circle of friends. \\
\hline & EV4 & enhances interaction among people. \\
\hline & EV5 & decreases face-to-face emotional interaction among people. \\
\hline & EV6 & provides the learning environment that I have benefited from the impact. \\
\hline & EV7 & provides more new knowledge. \\
\hline
\end{tabular}

We followed the guidelines of Hair, Ringle, and Sarstedt (2013) to report the PLS-SEM approach. Since PLS-SEM is a nonparametric approach, therefore it does not require the data to be normally distributed. However, it is important to verify that the data are not far from normal distribution. Subsequently, skewness and kurtosis were used prior to data analysis to evaluate the extent to which a variable's distribution is symmetrical (Hair et al., 2013). The skewness and kurtosis values of most items were ranged between -1 and +1 , which are well below the levels suggested for transformation of variables (Ghisseli, Campell, \& Zedeck, 1981). Thereby, non-normality of data is not an issue for the research. Furthermore, common method bias was assessed by conducting Harman's single factor (Podsakoff, MacKenzie, Lee, \& Podsakoff, 2003). Accordingly, single factor 
accounted for the majority of variance explained (19.14\% only). This suggests that common method bias is not a major issue in this study.

\subsection{Demographic Profiles of Respondents}

Table 2 depicts the demographic profile of 197 respondents in Malaysia. The demographic profile includes the respondents' gender, age, race, highest education level, monthly salary, monthly mobile subscription, and their most recent subscription.

Table 2. Demographic profile of respondents $(n=197)$

\begin{tabular}{|c|c|c|c|}
\hline Variable & Categories & Frequency & Percentage \\
\hline \multirow{2}{*}{ Gender } & Male & 61 & 31.3 \\
\hline & Female & 134 & 68.7 \\
\hline \multirow{4}{*}{ Age } & $18-22$ & 128 & 69.9 \\
\hline & $23-27$ & 25 & 13.6 \\
\hline & $28-32$ & 19 & 10.3 \\
\hline & $33-37$ & 11 & 5.8 \\
\hline \multirow{4}{*}{ Race } & Malay & 56 & 28.6 \\
\hline & Chinese & 114 & 58.2 \\
\hline & Indian & 3 & 1.5 \\
\hline & Others & 23 & 11.7 \\
\hline \multirow{5}{*}{ Highest educational level } & High school (SPM) & 1 & 0.5 \\
\hline & Diploma/Matriculation/STPM & 22 & 11.2 \\
\hline & Bachelor's degree & 129 & 65.8 \\
\hline & Master's & 31 & 15.8 \\
\hline & $\mathrm{PhD}$ & 13 & 6.6 \\
\hline \multirow{6}{*}{ Monthly salary } & Less than RM1000 & 131 & 77.5 \\
\hline & RM1000-2000 & 15 & 8.9 \\
\hline & RM2001-3000 & 9 & 5.3 \\
\hline & RM3001-4000 & 6 & 3.6 \\
\hline & RM4001-5000 & 5 & 3.0 \\
\hline & More than RM5000 & 3 & 1.8 \\
\hline \multirow{5}{*}{ Monthly subscription } & Less than RM50 & 78 & 40.8 \\
\hline & RM50-100 & 75 & 39.3 \\
\hline & RM101-150 & 29 & 15.2 \\
\hline & RM151-200 & 6 & 3.1 \\
\hline & More than RM200 & 3 & 1.6 \\
\hline \multirow{5}{*}{ Current subscription to mobile operator } & Celcom & 51 & 21.1 \\
\hline & Digi & 63 & 27.4 \\
\hline & Maxis & 57 & 24.2 \\
\hline & Umobile & 16 & 2.6 \\
\hline & Others & 14 & 1.6 \\
\hline
\end{tabular}

According to Table 1, the female respondents are more than double that of the number of male respondents with a rate of $68.7 \%$ female versus $31.3 \%$ male. The age of respondents in this category varies. In fact, about $70 \%$ of respondents aged between 18 and 22 years old, while only $30 \%$ of respondents aged between 22 and 37 years old. Therefore, the results show that the majority of respondents were in the range of generation Y (i.e., birthdate years between 1980s and 2000s). More than half of the respondents were Chinese (58.2\%), while $28.6 \%$ were Malays, and only $1.5 \%$ of respondents were Indians. 
The majority of respondents were educated, having bachelor's degree $(65.8 \%)$, master's $(15.8 \%)$, and $\mathrm{PhD}$ (6.6\%). $77 \%$ of the respondents had a monthly salary of less than RM1000, which shows the majority were students at the university level, while the rest had a salary above that amount. $40.8 \%$ of the respondents as mobile users spent less than RM50 monthly on mobile subscription. Similarly, about the equal numbers of respondents spent between RM50 and RM100 on monthly subscription, while only $1.6 \%$ spent over RM200 on mobile subscription. In general, mobile users in Malaysia closely used different mobile network operators. It shows high competition in the telecommunications sector. For example, Digi is number one in terms of subscription among the respondents by $27.4 \%$. Maxis comes second after Digi with $24.2 \%$, and Celcom (21.1\%) respectively. Umobile is a newly introduced brand to the market and has yet to be recognized among the mobile users.

\subsection{Measurement Model}

The e-lifestyle instrument was adapted in this study which was originally developed by Wells and Tigert (1971) and Mitchell (1983), and adapted by the seminal work of Yu (2011). The questionnaire comprised of 28 items to measure the dimension of e-activities ( 8 items), e-interests ( 7 items), e-opinions (6 items), and e-values ( 7 items) The questionnaire with a five-point Likert scale, ranging from 1 (strongly disagree) to 5 (strongly agree) was used to collect the data. The instrument was hence adapted based on the Malaysian-response context. The questionnaire consisted of two major sections. The first section included four sub constructs underlying consumer e-lifestyle. The construct of e-lifestyle is considered as the second-order construct. Four first-order constructs adapted from previous research are defined for the e-lifestyle construct (Mitchell, 1983; Wells \& Tigert, 1971; Yu, 2011).

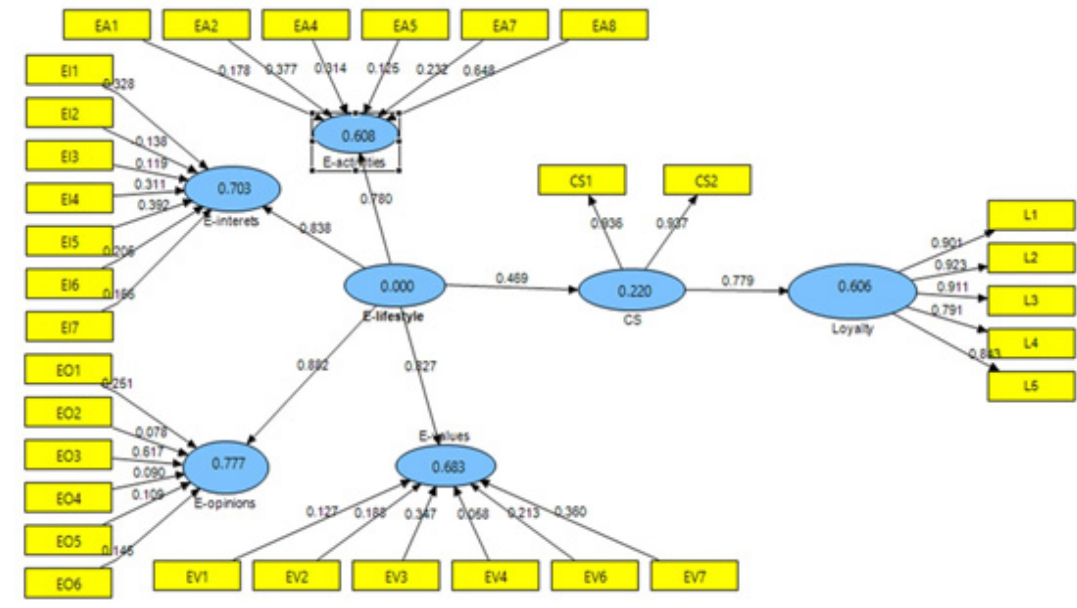

Figure 2. Measurement model

The measurement model (see Figure 2) results are comprised of two sections; formative and reflective assessment. In order to assess the validity of formative constructs, several steps need to be done sequentially. First, scholars need to assess multicollinearity issue for the formative indicators (Peng \& Lai, 2012). High correlations between two formative indicators can have an effect on the results as it boosts the standard error and reduces the ability to demonstrate that the estimated weights are different from zero (Hair et al., 2013). Variance inflation factor is a used means to assess the multicollinearity issue (Petter, Straub, \& Rai, 2007). In the context of PLS-SEM, a VIF value of 5 and higher indicates a potential collinearity problem (Hair, Ringle, \& Sarstedt, 2011b). Second, scholars should assess each formative indicator's contribution to the formative construct score which is created by aggregating the formative indicators of a construct using the item's weight (Götz, Liehr-Gobbers, \& Krafft, 2010). The item's weight should be significant, the sign of item weight should be consistent with the underlying theory, and the magnitude of the item weight should be greater than 0.10 (Andreev, Hearty, Maozz, \& Pliskin, 2009).

Four formative constructs (i.e., e-activities, e-interests, e-opinions, and e-values) in the research were assessed for validity using VIF and outer weighting significance results. Table 3 depicts that the VIF value is lower than 5 for all four constructs of e-lifestyle. Hence, collinearity issues are not at the critical level for the second-order construct of e-lifestyle. Therefore, the first assessment's step of the formative constructs is met, hence item 
weight in formative measurement models should be analyzed for their significance and relevance as the second step for formative measurement assessment (Hair et al., 2013). A bootstrapping procedure generating 5000 subsamples was used to test whether the outer weights in formative measurement models are significantly different from zero.

Table 3. Collinearity statistics

\begin{tabular}{|c|c|c|c|c|c|c|c|}
\hline \multicolumn{2}{|l|}{ E-activities } & \multicolumn{2}{|l|}{ E-interests } & \multicolumn{2}{|l|}{ E-opinions } & \multicolumn{2}{|l|}{ E-values } \\
\hline Indicators & VIF & Indicators & VIF & Indicators & VIF & Indicators & VIF \\
\hline EA1 & 1.143 & EI1 & 1.480 & EO1 & 1.521 & EV1 & 1.395 \\
\hline EA2 & 1.403 & EI2 & 1.855 & $\mathrm{EO} 2$ & 1.415 & EV2 & 1.582 \\
\hline EA3 & 1.672 & EI3 & 2.088 & $\mathrm{EO} 3$ & 1.682 & EV3 & 1.821 \\
\hline EA4 & 1.220 & EI4 & 1.748 & EO4 & 1.405 & EV4 & 1.738 \\
\hline EA5 & 1.350 & EI5 & 1.447 & EO5 & 1.454 & EV5 & 1.053 \\
\hline EA6 & 1.605 & EI6 & 1.523 & EO6 & 1.383 & EV6 & 1.776 \\
\hline EA7 & 1.270 & EI7 & 1.128 & & & EV7 & 1.964 \\
\hline EA8 & 1.138 & & & & & & \\
\hline EA9 & 1.134 & & & & & & \\
\hline
\end{tabular}

Table 4. Validity results of formative first-order constructs

\begin{tabular}{llll}
\hline Formative constructs & Formative indicators & Item weight (Item loading) & T statistics \\
\hline \multirow{4}{*}{ E-activities } & EA1 & $0.178(0.285)$ & $1.757^{* *}$ \\
& EA2 & $0.376(0.383)$ & $3.779^{* * *}$ \\
& EA4 & $0.314(0.550)$ & $2.614^{* * *}$ \\
& EA5 & $0.125(0.404)$ & 1.269 \\
EA7 & $0.232(0.532)$ & $2.079^{* *}$ \\
EA8 & $0.648(0.707)$ & $6.584^{* * *}$ \\
EI1 & $0.328(0.711)$ & $3.066^{* * *}$ \\
EI2 & $-0.138(0.418)$ & $1.374^{*}$ \\
E-interests & EI3 & $0.119(0.593)$ & 1.249 \\
& EI4 & $0.316(0.787)$ & $2.747^{* * *}$ \\
EI5 & $0.392(0.773)$ & $3.768^{* * *}$ \\
EI6 & $0.205(0.693)$ & $2.013^{* *}$ \\
EI7 & $0.166(0.385)$ & $1.876^{* *}$ \\
EO1 & $0.251(0.742)$ & $3.275^{* * *}$ \\
E-opinions & EO2 & $0.078(0.615)$ & $1.131^{\mathrm{NS}}$ \\
& EO3 & $0.617(0.928)$ & $7.902^{* * *}$ \\
& EO4 & $0.090(0.604)$ & $1.291^{*}$ \\
EO5 & $0.109(0.572)$ & $1.473^{*}$ \\
E-values & EO6 & $0.146(0.527)$ & $2.051^{* *}$ \\
& EV1 & $0.127(0.626)$ & $1.364^{*}$ \\
EV2 & $0.188(0.727)$ & $1.956^{* *}$ \\
EV3 & $0.347(0.801)$ & $3.355^{* *}$ \\
EV4 & $0.058(0.660)$ & $0.693^{\mathrm{NS}}$ \\
& EV6 & $0.213(0.763)$ & $1.838^{* *}$ \\
& EV7 & $0.360(0.847)$ & $3.003^{* * *}$ \\
\hline
\end{tabular}

Note: $\mathrm{NS}=$ not significant. ${ }^{*} p<0.10,{ }^{* *} p<0.05,{ }^{* * *} p<0.01$. 
Table 4 illustrates the assessment of formative constructs using the items weight's significance. E-activities have a total of nine formative items. The weights for three items are not significant (i.e., EA3, EA6, and EA9). Additionally, their outer loadings are less than the value of 0.50 . Therefore, they need to be removed from the data sample set. Seven indicators of e-interest are significant at either $99 \%$ or $90 \%$ confidence level. All seven formative indicators of e-interest have item's weight value above 0.10 and are statistically significant. For the construct of e-opinion, out of six formative indicators, four of them have item weight value above 0.10 , while EO2 is not significant. However, since their item loadings are above the value of 0.50 (i.e., 0.615), they have to remain in the model of the study. Five indicators of e-values have item weight above the value of 0.50 and significant at $99 \%, 90 \%$, and $95 \%$ confidence levels. EV4 is not significant; however, it remained in the model as its representative item loading is above 0.50 with a value of 0.660 . Moreover, other items were removed from the model, which were either not significant nor have item loadings above the value of 0.50 .

According to Tables 2 and 3, the validity of the formative measurement models among the first-order constructs is assessed. The next section includes the results of validity and reliability of the reflective measurement models for first-order constructs.

\subsection{Reflective Measurement Results}

Reflective measurement model assessment in the PLS analysis includes composite reliability (CR) to evaluate internal consistency among items for each construct, item loading, and average extracted variance (AVE) to assess convergent validity. It also involves cross-loading and Fornell-Larcker criterion to evaluate discriminant validity among constructs of the research model of study (Chin, 1998; Hair et al., 2013; Henseler, Ringle, \& Sinkovics, 2009). Item loadings and reliabilities were examined to evaluate the properties of the reflective measurement models. Item loading should be 0.708 or higher that a latent variable can explain a substantial part of each indicator's variance (Hair et al., 2013). Table 4 depicts the item loadings for all reflective measurement items which are almost above the value of 0.708 . CRs for constructs were confirmed satisfactory with values above 0.70 (see Table 5) (Fornell \& Larcker, 1981). Hence, the internal consistency among the items for each construct is confirmed.

Moreover, Table 4 illustrates the AVE values for each construct of the study model. AVE is well-defined as the mean value of the squared item loadings associated with the construct and an AVE value of 0.50 or higher is adequate for each construct to explain more than half of its correspondent items (Hair et al., 2013). According to Table 5, AVE values for all constructs are above 0.50 , hence it is satisfactory.

Table 5. Convergent validity and reliability results of constructs

\begin{tabular}{lllll}
\hline Constructs & Item & Loading & CR & AVE \\
\hline Customer satisfaction & CS1 & 0.936 & 0.935 & 0.877 \\
Loyalty & CS2 & 0.937 & & \\
& L1 & 0.901 & 0.942 & 0.766 \\
L2 & 0.923 & & \\
L3 & 0.911 & & \\
E-lifestyle & L4 & 0.791 & & \\
& L5 & 0.843 & & \multirow{2}{*}{0.767} \\
& EA & 0.811 & & \\
& EI & 0.863 & & \\
\hline
\end{tabular}

In PLS analysis, two criteria were used to evaluate the discriminant validity (i.e., cross-loading and correlation) of the reflective measurement models. First, items should load more strongly on their correspondent constructs than on other constructs. Second, the square root of each construct's AVE should be higher than the level of correlations involving the construct (Chin, 1998). Table 6 illustrates the cross-loading for the second-order constructs which shows that the main loading under each construct is higher than the cross-loading for other constructs. 
Table 6. Cross-loading results of second-order constructs

\begin{tabular}{llll}
\hline Item & Customer satisfaction & E-Lifestyle & Loyalty \\
\hline CS1 & $\mathbf{0 . 9 3 7}$ & 0.446 & 0.708 \\
CS2 & $\mathbf{0 . 9 3 7}$ & 0.374 & 0.750 \\
EA & 0.322 & $\mathbf{0 . 8 1 1}$ & 0.304 \\
EI & 0.355 & $\mathbf{0 . 8 6 3}$ & 0.376 \\
EO & 0.470 & $\mathbf{0 . 9 8 8}$ & 0.454 \\
EV & 0.368 & $\mathbf{0 . 8 2 9}$ & 0.356 \\
L1 & 0.751 & 0.432 & $\mathbf{0 . 9 0 1}$ \\
L2 & 0.723 & 0.418 & $\mathbf{0 . 9 2 3}$ \\
L3 & 0.729 & 0.380 & $\mathbf{0 . 9 1 1}$ \\
L4 & 0.548 & 0.263 & $\mathbf{0 . 7 9 1}$ \\
L5 & 0.629 & 0.369 & $\mathbf{0 . 8 4 3}$ \\
\hline
\end{tabular}

Fornell-Larcker criteria need to be evaluated to confirm the discriminant validity of the reflective constructs of second-order models. Therefore, inter-construct correlation statistics were examined during the measurement model assessment (see Table 7). As shown in Table 7, all constructs share more variance with their items (AVE) than with other constructs. Additionally, all the correlations are below the cutoff value of 0.80 (Hair, Black, Babin, \& Anderson, 2010). Since both cross-loading and Fornell-Larcker criteria are met, discriminant validity among constructs of the study is confirmed.

Table 7. Inter-construct correlations

\begin{tabular}{lllc}
\hline Variables & $\mathbf{1}$ & $\mathbf{2}$ & $\mathbf{3}$ \\
\hline 1.Customer satisfaction & $\mathbf{0 . 9 3 7}$ & & \\
2. E-lifestyle & 0.438 & $\mathbf{0 . 8 7 6}$ & $\mathbf{0 . 8 7 5}$ \\
3. Loyalty & 0.779 & 0.430 & $\mathbf{0 . 4 5 0}$
\end{tabular}

Notes: $\mathrm{N}=197$. Diagonals (in bold) represent the square root of the average variance extracted and off-diagonals represent the correlation.

Overall, internal reliability, convergent validity, and discriminant validity were assessed for the measurement model of the study and they are proved by conducting several statistical approaches. Therefore, we can conclude that our model has adequate validity and reliability to continue with analysis of the structural model.

\subsection{Structural Model Results}

Prior to assessment of structural model, collinearity issues need to be examined between the constructs of the study. To do so, variance inflation factor (VIF) is a commonly used approach to detect multicollinearity (Petter et al., 2007). In PLS analysis, a VIF value of five and higher indicates a potential problem of collinearity (Hair, Ringle, \& Sarstedt, 2011a). Based on the results of VIF tests, VIF values for all constructs were less than five which reveals no collinearity issue (see Table 8).

Table 8. Collinearity statistics

\begin{tabular}{ll}
\hline Constructs & VIF \\
\hline E-lifestyle & 1.118 \\
Loyalty & 1.177 \\
Customer satisfaction & 1.239 \\
\hline
\end{tabular}

Table 9. Structural estimates

\begin{tabular}{lllll}
\hline Path & Path coefficient (Beta) & Standard Error & T Statistics & Decision \\
\hline CS -> Loyalty & 0.779 & 0.028 & $27.436^{* * *}$ & Supported \\
E-Lifestyle -> CS & 0.438 & 0.060 & $7.276^{* * *}$ & Supported \\
\hline
\end{tabular}

Note: ${ }^{*} \mathrm{p}<0.05,{ }^{* *} \mathrm{p}<.01,{ }^{* * *} \mathrm{p}<0.001$, one-tailed. 
The results of the structural model estimates are illustrated in Table 9. We run the structural model using the bootstrap procedure by generating 5000 resamples as recommended by Hair et al. (2013). According to Table 9, as the $t$ statistics and standard error indicate, all path coefficients are significant.

Based on the results from Table 9, all hypotheses are supported at 99\% confidence level. In addition to path coefficient results, Table 10 indicates the complementary evaluation tools for structural model results. Accordingly, the $R^{2}$ values of endogenous constructs are illustrated for all four major mobile network operators in Malaysia. $19.2 \%$ of variations in customer satisfaction can be explained by construct of e-lifestyle, while $60.2 \%$ of variations in loyalty can be explained by construct of customer satisfaction.

Table 10. $R^{2}$, Predictive relevance, and effect size

\begin{tabular}{llll}
\hline Constructs & $\boldsymbol{R}^{2}$ & Communality (AVE) & $\boldsymbol{Q}^{2}$ \\
\hline E-lifestyle & - & 0.767 & - \\
Customer satisfaction & 0.192 & 0.877 & 0.168 \\
Loyalty & 0.606 & 0.766 & 0.461 \\
\hline
\end{tabular}

Stone-Geisser's $Q^{2}$ for endogenous constructs are 0.168 and 0.461 for customer satisfaction and loyalties, indicating acceptable predictive relevance as their values are above zero. Regarding Goodness of Fit (GoF), this approach has been challenged recently as it does not represent a good-of-fit criterion in PLS-SEM since it is unable to make distinction between a valid model from an invalid model (Henseler \& Sarstedt, 2012). Therefore, researchers are not advised to apply this approach for assessment of overall quality of the model.

Overall, two hypotheses developed in this study are supported based on the results obtained from the PLS analysis. In particular, based on the measurement model results, the first-order constructs of e-lifestyle carried different weight. For example, e-activities have the lowest item weight, while e-values have the highest weight. This shows the significant focus of consumers on values and belief when they subscribe to a particular mobile service provider.

\section{Conclusion}

In today's dynamic global environment, it is important to understand how consumer's e-lifestyle affects customer satisfaction-loyalty relationship toward the mobile service provider. The competition among the mobile service providers in Malaysia is more intense now than ever before as the market has not yet reached its optimal level and there are still ample opportunities to enhance their services. Surprisingly, the four major dimensions of e-lifestyle concurred with the key features of formative measurement models. Furthermore, this study has estimated a second-order formative-reflective model of consumer e-lifestyle using the repeated indicator approach suggested by previous scholars (Becker, Klein, \& Wetzels, 2012; Hair et al., 2013). Indeed, the outcome of this research has provided a more rigorous psychometric result compared to the previous research which commonly measure e-lifestyle reflectively (e.g., Yu, 2011). The psychometric results can be explored through the practical evidence of measurement parameter estimates such as item weight value, the absence of multicollinearity, and nomological validity in the format of second-order formative-formative model.

\section{Acknowledgements}

The authors would like to thank Universiti Sains Malaysia for funding this research under the Research University grant no. 1001/PMGT/816203.

\section{References}

Acedo, F. J., \& Jones, M. V. (2007). Speed of internationalization and entrepreneurial cognition: Insights and a comparison between international new ventures, exporters and domestic firms. Journal of World Business, 42(3), 236-252. http://dx.doi.org/10.1016/j.jwb.2007.04.012

ADB. (2008). Expanding horizons: A study on the development of the Indonesia, Malaysia, Thailand Growth-Triangle Economic Connectivity Corridors Asian Development Bank.

Andreev, P., Hearty, T., Maozz, H., \& Pliskin, N. (2009). Validating formative partial least squares (PLS) models: Methodological review and empirical illustration. Paper presented at the ICIS 2009 Proceedings.

Bates, J. M., Cooper, D. L., \& Wachs, P. M. (2001). Assessing wellness in college students: A validation of the salubrious lifestyle scale of the student developmental task and lifestyle assessment. Journal of College Student Development, 42(3), 93-203. 
Becker, J. M., Klein, K., \& Wetzels, M. (2012). Hierarchical latent variable models in PLS-SEM: Guidelines for using reflective-formative type models. Long Range Planning, 45(5-6), 359-394. http://dx.doi.org/10.1016/j. lrp.2012.10.001

Biel, A. L. (1992). How brand image drives brand equity. Journal of Advertising Research, 32(11), 6-12.

Blackwell, R. D., Miniard, P. W., \& Engel, J. F. (2001). Consumer behavior (9th ed.). Orlando, FL: Harcourt.

Chaney, D. (1996). Lifestyles. London: Routledge.

Chen, T. Y., \& He, Q. Y. (2006). Applying decision tree techniques to segmentation bases for e-marketing. Management Science Research, 3(1), 1-25.

Chin, W. W. (1998). The partial least squares approach to structural equation modeling. In G. A. Marcoulides (Ed.), Modern methods for business research. Mahwah, NJ: Lawrence Erlbaum Associates.

Demby, E. (Ed.). (1974). Psychographics and from where it came. Chicago, IL: American Marketing Association.

Dick, A. S., \& Basu, K. (1994). Customer loyalty: Toward an integrated conceptual framework. Journal of the Academy of Marketing Science, 99-113. http://dx.doi.org/10.1177/0092070394222001

Fornell, C. (1992). A national customer satisfaction barometer: The Swedish experience. Journal of Marketing, $55(1), 1-2$.

Fornell, C., \& Larcker, D. F. (1981). Structural equation models with unobservable variables and measurement error: Algebra and statistics. Journal of Marketing Research, 18(3), 328-388. http://dx.doi.org/10.2307/315 0980

Ghisseli, E. E., Campell, J. P., \& Zedeck, S. (1981). Measurement theory for the behavioral sciences. San Francisco, CA: Freeman.

Götz, O., Liehr-Gobbers, K., \& Krafft, M. (2010). Evaluation of structural equation models using the partial least squares (PLS) approach. In V. Esposito-Vinzi, W. W. Chin, J. Henseler, \& H. Wang (Eds.), Handbook of partial least squares: Concepts, methods, and applications (pp. 691-711). Berlin, Germany: Springer-Verlag. http://dx.doi.org/10.1007/978-3-540-32827-8_30

Green, G. T., Cordell, H. K., Betz, C. J., \& DiStefano, C. (2006). Construction and validation of the national survey on recreation and the environment's lifestyles scale. Journal of Leisure Research, 38(4), 513-535.

Hair, J. F., Black, W. C., Babin, B. J., \& Anderson, R. E. (2010). Multivariate data analysis. Englewood Cliffs, NJ: Prentice-Hall.

Hair, J. F., Ringle, C. M., \& Sarstedt, M. (2011a). PLS-SEM: Indeed a silver bullet. Journal of Marketing Theory and Practice, 18(2), 139-152. http://dx.doi.org/10.2753/MTP1069-6679190202

Hair, J. F., Ringle, C. M., \& Sarstedt, M. (2011b). The use of partial least squares (PLS) to address marketing management topics: From the special issue guest editors. Journal of Marketing Theory and Practice, 18(2), 135-138.

Hair, J. F., Ringle, C. M., \& Sarstedt, M. (2013). A primer on Partial Least Squares Structural Equation Modelling (PLS-SEM). Thousand Oaks: California SAGE Publications, Inc.

Hair, J. F., Sarstedt, M., Ringle, C. M., \& Mena, J. A. (2012). An assessment of the use of partial least squares structural equation modeling in marketing research. Journal of the Academy of Marketing Science, 40(3), 414-433. http://dx.doi.org/10.1007/s11747-011-0261-6

Henseler, J., \& Sarstedt, M. (2012). Goodness-of-fit indices for partial least squares path modeling. Computational Statistics.

Henseler, J., Ringle, C. M., \& Sinkovics, R. R. (2009). The use of partial least squares path modeling in international marketing. In R. R. Sinkovics, \& P. N. Ghauri (Eds.), Advances in International Marketing (Vol. 20, pp. 277-320). Bingley: Emerald.

Hur, W. M., Kim, H. K., \& Park, J. (2010). Food and situation-specific lifestyle segmentation of kitchen appliance market. British Food Journal, 112(3), 294-312. http://dx.doi.org/10.1108/00070701011029165

Inkpen, A. C., \& Birkenshaw, J. (1994). International joint ventures and performance: An interorganizational perspective. International Business Review, 3(3), 201-217. http://dx.doi.org/10.1016/0969-5931(94) 90002-7

Karnowski, V., \& Jandura, O. (2014). When lifestyle becomes behavior: A closer look at the situational context of mobile communication. Telematics and Informatics, 31(2), 184-193. http://dx.doi.org/10.1016/j.tele.2013. 11.001

Kaynak, E., \& Kara, A. (2001). An examination of the relationship among consumer lifestyles, ethnocentrism, knowledge structures, attitudes and behavioural tendencies: A comparative study in two CIS states. International Journal of Advertising, 20(4), 457-482. 
Lam, S. Y., Shankar, V., Erramilli, M. K., \& Murthy, B. (2004). Customer value, satisfaction, loyalty, and switching costs: An illustration from a business-to-business service context. Journal of the Academy of Marketing Science, 32(3), 293. http://dx.doi.org/10.1177/0092070304263330

Lazer, W. (Ed.). (1963). Lifestyle concepts and marketing. Chicago, IL: American Marketing Association.

Lee, H. J., Lim, H., Jolly, L. D., \& Lee, J. (2009). Consumer lifestyles and adoption of high-technology products: A case of South Korea. Journal of International Consumer Marketing, 21(2), 153-167. http://dx.doi.org/10. 1080/08961530802153854

Levesque, T., \& McDougall, G. H. G. (1996). Determinants of customer satisfaction in retail banking. International Journal of Bank Marketing, 14(7), 12-20. http://dx.doi.org/10.1108/02652329610151340

Lin, F. Y. (2003). An analysis of hospitality consumer lifestyles in the United States. PhD dissertation, Texas Tech University, Lubbock, TX.

Mano, H., \& Oliver, R. L. (1993). Assessing the dimensionality and structure of the consumption experience: Evaluation, feeling, and satisfaction. Journal of Consumer Research, 20, 451-466. http://dx.doi.org/10.1086/209361

Mitchell, A. (1983). The nine American lifestyles. New York, NY: Warner.

Murry, J. P., Lastovicka, J. L., \& Austin, J. R. (Eds.). (1997). The value of understanding the influence of lifestyle trait motivations on consumption beliefs. Mahwah, NJ: Lawrence Erlbaum.

Peng, D. X., \& Lai, F. (2012). Using partial least squares in operations management research: A practical guidelines and summary of past research. Journal of Operations Management, 30, 467-480. http://dx.doi. org/10.1016/j.jom.2012.06.002

Penz, E. (2006). Researching the socio-cultural context: Putting social representations theory into action. International Maketing Review, 23(4), 418-437. http://dx.doi.org/10.1108/02651330610678985

Petter, S., Straub, D., \& Rai, A. (2007). Specifiying formative constructs in information system research. MIS Quarterly, 31(4), 623-656.

Podsakoff, P. M., MacKenzie, S. B., Lee, J. Y., \& Podsakoff, N. P. (2003). Common method biases in behavioral research: A critical review of the literature and recommended remedies. Journal of Applied Psychology, 88(5), 879-903. http://dx.doi.org/10.1037/0021-9010.88.5.879

Rauyruen, P., \& Miller, K. E. (2007). Relationship quality as a predictor of B2B customer loyalty. Journal of Business Research, 60(1), 21-31. http://dx.doi.org/10.1016/j.jbusres.2005.11.006

Ringle, C. M., Wende, S., \& Will, A. (2005). SmartPLS 2.0 (M3) Beta. Hamburg, Germany. Retrieved from http://www.smartpls.de

Tsang, E. W. K. (2002). Acquiring knowledge by foreign partners from international joint ventures in a transition economy: Learning-by-doing and learning myopia. Strategic Management Journal, 23(9), 835-854. http://dx.doi.org/10.1002/smj.251

Vyncke, P. (2002). Lifestye segmentation: From attitudes, interests and opinoins, to values, aesthetics styles, life visions and media preferences. European Journal of Communication, 17(4), 445-463. http://dx.doi. org/10.1177/02673231020170040301

Wells, W., \& Tigert, D. (1971). Activities, interests, and opinions. Journal of Advertising Research, 11, 27-35.

Wong, Y. H., Chan, R. Y. K., Ngai, E. W. T., \& Oswald, P. (2009). Is customer loyalty vulnerability-based? An empirical study of a Chinese capital-intensive manufacturing industry. Industrial Marketing Management, 38(1), 83-93. http://dx.doi.org/10.1016/j.indmarman.2007.10.002

Yu, C. S. (2011). Construction and validation of an e-lifestyle instrument. Internet Research, 21(3), 214-235. http://dx.doi.org/10.1108/10662241111139282

Zeithaml, V. A., Berry, L. L., \& Parasuraman, A. (1996). The behavioral consequences of service quality. Journal of Marketing, 60, 31-46. http://dx.doi.org/10.2307/1251929

Zineldin, M. T. (2000). TRM total relationship management. Studentlitteratur: Lund.

\section{Copyrights}

Copyright for this article is retained by the author(s), with first publication rights granted to the journal.

This is an open-access article distributed under the terms and conditions of the Creative Commons Attribution license (http://creativecommons.org/licenses/by/3.0/). 